University of Maryland Francis King Carey School of Law

DigitalCommons@UM Carey Law

\title{
The Politics of Professionalism: Reappraising Occupational Licensure and Competition Policy
}

\author{
Sandeep Vaheesan
}

Frank A. Pasquale

University of Maryland Francis King Carey School of Law, fpasquale@law.umaryland.edu

Follow this and additional works at: https://digitalcommons.law.umaryland.edu/fac_pubs

Part of the Antitrust and Trade Regulation Commons, Consumer Protection Law Commons, Legal Ethics and Professional Responsibility Commons, and the Legal Profession Commons

\section{Digital Commons Citation}

Vaheesan, Sandeep and Pasquale, Frank A., "The Politics of Professionalism: Reappraising Occupational Licensure and Competition Policy" (2017). Faculty Scholarship. 1609.

https://digitalcommons.law.umaryland.edu/fac_pubs/1609

This Article is brought to you for free and open access by the Francis King Carey School of Law Faculty at DigitalCommons@UM Carey Law. It has been accepted for inclusion in Faculty Scholarship by an authorized administrator of DigitalCommons@UM Carey Law. For more information, please contact smccarty@law.umaryland.edu. 


\section{The Politics of Professionalism: Reappraising Occupational Licensure and Competition Policy}

Sandeep Vaheesan \& Frank Pasquale

\section{Introduction}

"The market" is not a natural or organic entity. Markets cannot and do not exist apart from the state. In any modern, complex economy, transactions require conventions and laws to be successfully and reliably consummated. Even if we aspired to a completely contractually governed economy, questions of enforcement and interpretation of such contracts would arise. Thus the market is always a product of extensive state action.

A so-called market economy requires property rights and tort law that are defined and enforced through the coercive mechanisms of the state. Contemporary capitalist or neoliberal social orders are dependent not only on common law doctrines such as trespass, alienability of property, and negligence but also on laws concerning copyright, patent, trademark, and corporate governance and the management of monetary policy by the Federal Reserve. Administrative agencies govern entire sectors of the economy. In short, the production and distribution of wealth are the result of conscious political decisions by the state, not preordained outcomes (Hale 1952, McCluskey 2012).

Sadly, these basic points are frequently forgotten among both policymakers and practicing lawyers. Some aspects of law are treated as natural and unquestionable (e.g., tort and contract), while others are persistently painted as a statist incursion into Edenic laissez-faire (e.g., labor law and consumer protections). Even more troublingly, certain areas of law have come to not merely reflect, but embody, this one-sidedness. American antitrust law, in particular, has been used to undermine the power of professionals and associations of workers, even as contemporary antitrust authorities treat some of the most powerful firms ever to exist—and their own collusion against workers - with kid gloves (Pasquale 2010b, Whitney 2015).

This bias in antitrust law reflects a larger cultural tilt in the United States toward consumer interests, and away from those producers (or, at least, the interests of productive workers at firms, as opposed to rentiers and capital generally) (Whitman 2007). ${ }^{1}$ Chicago School teachings have made an esoteric, mathematically defined account of "consumer welfare" the defining inquiry in antitrust. It is troubling enough that crabbed interpretations of monopolization and merger doctrine have acted as a shield to permit extraordinary levels of concentration in

\footnotetext{
${ }^{1}$ Note, however, that there is no necessary tension between the interests of labor and consumers along several axes. For example, consumers prefer well-trained doctors, plumbers, et al., and those laborers who are well-trained do not want to face unfair competition from fly-by-night operators who have not sufficiently invested in the skills necessary to do these jobs well.
} 
major U.S. industries (Economist 2016, Pasquale 2013b). On top of this deferential posture toward large businesses, the Federal Trade Commission (FTC) and Department of Justice (DOJ) use antitrust law as a sword, to challenge professions and worker associations that go too far in establishing standards of fair conduct, stable employment, and quality service in their fields.

Even as these initiatives, aimed at labor ranging from dentistry to ice skating coaching, may sometimes deter anticompetitive activity with no benefit to the economy as a whole, they can stifle beneficial collection action by workers. They signal a general disapproval of workers acting in concert and may undermine one of the few tools of self-assertion that workers can now brandish against powerful firms (ranging from digital labor platforms, like Uber or Amazon's mTurk, to an increasingly concentrated health care industry). Most problematically, present antitrust doctrine does not take into account the societal value of occupational licensure or professional standards. Instead, it reflects mainstream economics' bias against occupational licensure and a more general belief that government is the principal obstacle to competitive markets (Vaheesan 2015).

This article exposes weaknesses in the mainstream case against occupational licensure and worker self-organization (Part II). Sadly, antitrust law has failed to grapple with the thin empirical case against occupational self-governance and self-assertion (Part III). Therefore, it is essential for antitrust law to evolve toward a new position of respect for and openness to democratic governance within professions and occupations themselves, and laws recognizing that self-governance (Part IV).

\section{The Uneasy Case Against Occupational Licensure}

During the trentes glorieuses, labor's share of income relative to capital increased in the United States, thanks to favorable terms of globalization and legal protections for both unions and professions, among other factors (Piketty 2014). Consumer protection and disclosure laws also complicated the lives of firm managers. These progressive measures proved vulnerable to attack, however. Just as the Taft-Hartley Act of 1947 marked a backlash against labor's gains in the 1930s, the 1970s would see a variety of efforts to roll back what was perceived as a regulatory juggernaut of the 1960s.

The Powell Memo outlined a number of initiatives to combat what its author perceived as undue liberal influence in universities, labor movements, and civil society generally (Powell 1971). Regulators also came under attack. Those suspicious of the administrative state offered critical perspectives on the motives and results of licensing boards that controlled access to certain types of jobs. Walter Gellhorn complained that:

occupational licensing has typically brought higher status for the producer of services at the price of higher costs to the consumer; it has reduced competition; it has narrowed opportunity for aspiring youth by increasing the costs of entry into a desired occupational 
career; it has artificially segmented skills so that needed services, like health care, are increasingly difficult to supply economically; it has fostered the view that unethical practices will prevail unless those entrenched in a profession are assured of high incomes; and it has caused a proliferation of official administrative bodies, most of them staffed by persons drawn from and devoted to furthering the interests of the licensed occupations themselves (Gellhorn 1976).

Gellhorn's laundry list of objections later blossomed into think tank position papers and economic research. The American Enterprise Institute now laments the "terrible economic burden of occupational licensing." (Pethokoukis 2014). Technocratic liberals join the dirge, and often put the dismantling of many occupational licensure requirements at the very top of a proposed bipartisan agenda to promote economic growth (along with cuts to entitlements and health care spending).

A rough typology of complaints against occupational licensure would include the following: it raises prices for consumers without commensurate increases in quality, and blocks out would-be competitors who cannot or will not undergo requisite training and tests. However, each of these objections is not sufficiently theorized, justified, or empirically grounded to support the types of interventions now routinely pursued by the Federal Trade Commission and Department of Justice. Commentators all too often extrapolate from horror stories to make claims about the entirety of licensing, peddling anecdata disconnected from the complex and variegated reality of contemporary labor practices.

\section{A. Price and Quality}

In the basic case against occupational licensure, the focus is on the higher prices arising from these regulations. There is a presumption that the price increase in, say, medical or legal services, due to the training and testing of licensed professionals in such fields, is not worth the wedge of price increase attributable to the cost of such training and testing. But there is little awareness of the real potential for consumers to capture that wedge of price. For example, if training requirements for nurses declined, perhaps hospitals would pay them lower starting salaries because they would not be burdened by such high student loan payments. But it is by no means clear that patients would see their bills fall. Instead, managers and shareholders may simply pocket the reduced wage - resulting in a hat trick of declining quality of labor, rising inequality, and less resources for the types of professional schools whose research advances nursing practice.

A more advanced version of the "higher-price-without-greater-quality" case depends on the rise of big data and forms of popular assessment to empower consumers to make their own judgments as to price/quality tradeoffs. Regina Herzlinger proposes ratings for drugs, rather than FDA approval or nonapproval decisions; a similar regime could rate doctors or lawyers, displacing extant licensing of such professionals. (Pasquale 2013a, Pasquale 2010c). According 
to the usual economic logic, such tiered rating (rather than all-or-nothing licensure) of medical and legal professionals would expand access in both fields.

However, such a perspective ignores the predictable costs of terrible providers. Moreover, it is an open invitation to fraud and abuse: there is widespread public funding for medicine, or contingent or state funding for legal services. The United States has developed several redistributive mechanisms to fund health care, ranging from the Medicare payroll tax to general funds derived from progressive income taxation. Fly-by-night operations can easily take advantage of such funds. It is very easy to game rating and ranking systems.

There is also a question concerning how providers would earn their first star ratings or other indicia of quality. Perhaps those looking for experience would be a cheap option for the poor and disadvantaged. But creating such second-rate options for the poor undermines the unitary standard of care now underwritten by communal funding sources. Even if tiering and low-cost options would reduce the cost of care in many instances, there is no guarantee that this reduced cost will actually increase the real incomes of poor or middle class persons. Instead, it may simply result in reduced subsidies for health care from employers, or reduced state support. Moreover, those who would undermine extant institutions of medical or legal training rarely account for the value of the research generated by such institutions.

Opponents of occupational licensure have an unfortunate tendency to treat the most marginal or extreme cases of inappropriate or excessive licensing requirements, as paradigmatic of the entire field. Parades of horribles quickly emerge: S. David Young complains about licensure of "falconers, ferret breeders, and palm readers" (Young 2002); Gellhorn marveled at the need to license "beekeepers and taxidermists" (Gellhorn 1976); cosmetologists and florists are a frequent go-to example for libertarian litigators (Vong v. Aune 2014, Slivinski 2015). We obviously cannot comprehensively demonstrate the wisdom of training requirements in each of these diverse areas of human occupation (though at least in the case of beekeepers, the risk of disastrous mismanagement of stinging insects suggests some regulation is wise). But they are scarcely reflective of the hundreds of occupations now licensed by some jurisdiction in the United States (and certainly not of the 65 occupations required to be licensed in all 50 states).

Reflexive incredulity toward licensing requirements in certain fields is presumptuous, often reflecting an elitist, anti-worker outlook. It is also frequently hypocritical: the same commentators who would generalize from a critique of ferret breeder training to a deregulatory labor policy in general, would impose evidentiary strictures akin to the Data Quality Act on regulators before they expanded the scope of their authority. We believe that critics should demonstrate a Burkean humility before upsetting arrangements that have long governed these fields. It is easy to peer into any given occupation from the outside and exclaim, "what an easy job! Why on earth is a license required to do that?" It is harder to interview practitioners in the field and grasp the range of tasks their training may prepare them to undertake. To its credit, the 
White House report on occupational licensure does occasionally cite authors who complete such studies, and find positive effects from licensure. But such documents rarely consider the full implications of the complexity of the licensure landscape.

\section{B. Restrictions on Entry}

Once one moves beyond the "easy cases" of libertarian outrage at licensure, the uneasiness of the wholesale case against licensure becomes clear. For example, many occupations govern decisions that have sizeable and long-term consequences for those who do not directly engage in the economic transaction giving rise to the decision. For example, a thrifty apartment owner may find an unlicensed plumber to install pipes. If the pipes later leak thanks to the cheap plumber's lack of expertise, it is not merely the apartment owner who suffersneighbors and the entire building may be stricken with mold, structural damage, or worse. Similarly, granting prescribing authority to unlicensed medical professionals may create cheap options for the uninsured—-but increases risks of "pill mills" and other accoutrements of opioid epidemics.

Opponents of occupational licensing also rarely acknowledge that many professions do not require enough training before permitting relatively young and inexperienced individuals to take on enormous responsibility. One criminal justice expert argues that the current crisis of police shootings would be a far less widespread problem if officers had better training (Haberfeld 2016). Robert Kuttner has argued that elder care in the US is, at present, abysmal in many nursing homes - and that more professionalized home health aides would provide much better care (Kuttner 2008). Tragically, extant licensing laws are all too often underenforced even in very sensitive areas. Over a 10-year period, there were 43 deaths in unlicensed Virginia day care facilities (Falls \& Brittain 2014). The extreme vulnerabilities of ordinary citizens in each of these all-too-human experiences - being arrested, or being cared for during old or very young agecommend more regulation of personnel in these fields, not less.

Excess consumerism also skews scholarly perspectives here. While the harms of purchasing flowers from an unlicensed florist are not easy to fathom, consumer protection is not the sole goal or benefit from occupational licensing. A decision by the state to assure certain standards of quality in the provision of services like these is not entirely different in kind from a decision to decree a minimum wage, or mandate "closed shops" as a way to promote unions. Each regulation necessarily stops certain kinds of competition and shrinks a market relative to a less regulated benchmark.

Occupational licensing establishes what Eliot Freidson called "market shelters." (Freidson 1986). With these market shelters limiting entry, employers cannot draw on a large "reserve army" of unemployed individuals. By conferring greater bargaining power on workers, occupational regulations can raise wages and promote more stable employment. As history and more recent experience has shown, unfettered competition between workers in labor markets can 
be harmful. It can lead to below-subsistence level wages and unstable employment arrangements that harm individual workers, families, and entire communities. As with unionization and minimum wage laws, occupational licensing can grant workers greater power vis-à-vis employers and thereby has the potential to enhance the welfare of workers. It is no surprise that, as unionization rates have declined in the United States, the percentage of the workforce seeking licensure has increased.

\section{The Existing Antitrust Paradigm Is Not Capable of Accurately or Fairly Evaluating Occupational and Professional Regulations}

While antitrust law has informed and inspired the intellectual and legal attacks on occupational licensing (Goldfarb v. Va. State Bar 1975, Edlin \& Haw 2014), the current intellectual frame of antitrust cannot account for the myriad objectives of occupational regulations. Antitrust law today seeks to promote a very particular and arcane form of efficiency - allocative efficiency. This goal seeks to minimize the so-called deadweight loss from non-competitive pricing. The efficiency framework is untethered from the goals that Congress expressed when it enacted the antitrust laws. Unlike the vision expressed by the drafters of the Sherman, Clayton, and Federal Trade Commission Acts, antitrust's present efficiency paradigm disregards power dynamics in the economy and society (Orbach 2013). The neoclassical model omits the critical role of state institutions in enabling market activity in the first place and assumes a perfectly competitive marketplace that does not exist outside textbooks. Even from a strictly consumerist perspective, the efficiency model does not protect the full range of consumer interests and prizes short-term price competition over other considerations such as quality and safety (Pasquale 2013c, Pasquale 2006). Due to their narrow focus, in particular on short-term consumer prices, the efficiency-minded antitrust agencies have launched misguided attacks on occupational licensing.

\section{A. The Current Antitrust Framework Fails to Account for the Pluralistic Goals of Occupational and Professional Regulations}

Notwithstanding some intellectual disagreements at the margins, the extant antitrust regime prizes economic efficiency and treats other objectives as irrelevant. This technical concept of economic efficiency is derived from the neoclassical model and built on a pyramid of deductive reasoning. It is centered on a person's willingness and ability to pay for something. It does not consider a person's needs apart from his or her ability to acquire these needs. For example, an ill person's desire to obtain lifesaving health care is not accorded importance unless she has the means to purchase health care.

The principal or exclusive social harm under this framework is so-called deadweight loss in which some mutually beneficial market transactions do not occur due to some institutional impediment. Concerns about distribution and even longer-term economic efficiency are either treated as secondary or dismissed. So-called non-economic desires, such as preserving a 
particular industrial structure, maintaining the viability of local businesses, and protecting the living standards of workers, are deemed outside the scope of antitrust law.

The efficiency fixation does not reflect the Congressional goals of the antitrust laws. The sponsors of the antitrust laws had a broad vision for the new laws and sought to curtail concentrated private power and its many ill effects. Economists had not even invented the concept of economic efficiency when Congress passed the principal antitrust statutes in the late nineteenth and early twentieth centuries (Carstensen 1983).

Even leaving aside the legislative histories of the antitrust laws, the case for sacrificing popular social goals in the name of an arcane definition of efficiency is unpersuasive. Will Davies has acidly remarked on the extreme manipulability of the type of "aggregative" analysis characteristic of contemporary antitrust economics (Davies 2014). The concept of allocative efficiency prioritizes wealth maximization, leaving redistribution to be pursued later, if at all, via taxes and transfers (Kaplow \& Shavell 2000). This work largely ignores or discounts the possibility that unequal wealth attained under "optimal" substantive legal rules may be devoted to blocking political processes necessary to redistribute it (Kaplow \& Shavell 1994).

The goals of public policy are not cast in stone nor can they be removed from the realm of politics. Rather, they are contestable. Despite the claims of its proponents, efficiency is not a value-neutral concept. Efficiency maximization is laden with implicit political judgments on the role of the state, the existing distribution of wealth, and human behavior. Specifically, it demands that the state vigorously enforces rights of property and contracts and assumes that the existing distribution of wealth is somehow just or at least the result of neutral processes and that human behavior is motivated primarily or exclusively by self-interest (Flynn 1988). On the whole, the efficiency ideology tilts heavily in a conservative direction and is loath to upset the status quo (Hovenkamp 1985).

Astonishingly to a non-specialist observer, objectives such as consumer protection and employment stability play little to no role in antitrust case law focused on the professions and associations of workers. As one law casebook has noted:

There has long been a widespread agreement in the case law that antitrust inquiries should focus exclusively on competitive effects and should not take into account purported non-economic benefits of collective activities such as advancing social policies or even protecting public safety. This self-imposed boundary is based on the judiciary's skepticism about its competence to balance disparate social policies and the judgment that such concerns are more appropriately addressed to the legislature. Importantly, then, under Section One of the Sherman Act, courts will not consider justifications other than those asserting that a practice, on balance, promotes competition. ... [This] constraint is in obvious tension with justifications by professionals that their collective activities have 
the purpose of advancing the quality of patient care (Furrow et al. 2013, citing National Society of Professional Engineers v. United States 1978).

While plausible and even an admirable exercise of restraint on the surface, this account ignores political realities. The "judiciary's skepticism about its competence to balance disparate social policies" makes sense in the context of a concerned and democratically responsive Congress capable of responding flexibly to grant exemptions in cases where it judges public safety rationales to have merit. In a climate of nearly two decades of intensifying gridlock, however, it is a recipe for advantaging those able to take advantage of extant antitrust exemptions (like the Noer-Pennington doctrine and other broad conceptions of protected "speech") to further entrench their own power relative to those less advantageously positioned (Eastern Railroad Presidents Conference v. Noerr Motor Freight, Inc. 1961, United Mine Workers v. Pennington 1965. See also Citizens United v. Federal Election Comm'n 2010).

While some economists may dismiss public safety, industrial policy, or job stability as "illegitimate" goals according to their dogma, this assertion reflects an intellectual narrowness and blindness to developments in American society. Properly interpreted, antitrust law would empower courts to consider criteria of well-being besides short-term wealth maximizationparticularly when so much of that wealth has accrued to the top one percent of households (Pasquale 2010a, Pasquale 2014).

Moreover, antitrust law need not be entirely focused on consumer welfare, especially given changes in the balance of power between very large firms and workers. Over the past two generations, tens of millions of American have experienced stagnant wages and precarious employment. In this context, concerns about jobs and income are entirely valid and have become central to political debates. In the absence of stable, well-paying jobs, Americans are increasingly facing lives of material deprivation and chronic uncertainty. These afflictions are bad enough on their own, but also threaten dire macroeconomic consequences, as individuals subject to constant fear of losing a livelihood resist making rational investments in education or the types of consumption they would normally enjoy. For mainstream economists and antitrust lawyers to condemn occupational licensing on the grounds that it raises wages and generally helps workers is to elevate the preferences of one class of technocrats over democratic choices.

\section{B. The Current Antitrust Framework Fails to Consider Power in the U.S. Political Economy}

The efficiency model at the heart of current antitrust law also ignores power dynamics in American society in two critical ways. First, it submerges and naturalizes the essential role for state institutions in establishing and maintaining a market economy. Second, it relies on a model of perfect competition that disregards the power disparities that characterize the U.S. economy and have characterized it for centuries. 
The neoclassical model at the heart of antitrust law fails to acknowledge the important role of the state and public institutions in allowing markets to emerge and flourish. The capitalist economy is a state-ordered system. The neoclassical model and the associated language of "free markets" and "government intervention" obscure this truth. The textbook model of "efficient markets" requires widespread state action (Hale 1952, McCluskey 2012). Yet, this model assumes away these forms of state action and submerges, for example, property and contract rights that enable market activity into the state of nature preceding government institutions. This premise leads to the widespread belief that the state somehow emerges after markets are already flourishing - either improving market outcomes on occasion according to one school of thought or only impeding market efficiency according to a rival camp. A belief in this model can produce claims that property rights are "natural," but occupational licensing is an unjustified state imposition.

In addition to naturalizing the performance of certain state functions, current antitrust law uses perfect competition as its intellectual starting point. Under this stylized model, no partyconsumer, firm or worker - has power to influence prices or other quantities in the market. Everyone sells a commodified good or service at the competitive price, no higher and no lower. This conception of the market is the successor to Adam Smith's idealized view of a market in which all participants are equals and answer to no authority except the invisible hand of collective decisions by buyers and sellers. The model of perfect competition has been at the heart of many defenses of existing economic arrangements in the United States and capitalism generally.

Even when monopoly or oligopoly cannot be denied, the defenders of efficiency have a readymade response. They assume that market entry is easy and so all markets are "contestable" by firms waiting on the sidelines. In this view, monopoly and oligopoly are fleeting phenomenon soon defeated by new firms pursuing profit opportunities (e.g., Easterbrook 1984).

While this model is simple and appealing in imagining a system in which no single actor or even a group of actors exercises power over others, it is detached from contemporary political economy. Perfect competition is an ideal that is, for all intents and purposes, not seen in the U.S. economy. The example of perfect competition often cited in textbooks and by economistsagriculture - is far from competitive, let alone perfectly competitive. Rather, a defining characteristic is the highly concentrated agricultural processing sector (Hendrickson \& Heffernan 2007), which can dictate the terms at which American farmers can sell their products. The assumptions of free entry and contestable markets are also convenient assumptions, rarely seen in practice.

Most sectors of the economy are monopolistic or oligopolistic, with product differentiation being a defining characteristic of modern commerce. Sectors ranging from airlines to pharmaceuticals to telecom are dominated by a small number of corporations (Porter 2016). 
Moreover, despite claims of new competition and openness in the economy, the technology sector appears to be the antithesis of vigorous competition. Five large platforms dominate this "new economy," (Manjoo 2016) and two companies have a 70 percent share in the national broadband market (Farivar 2016).

In this world of monopoly and oligopoly power, some actors have great power while others have very little. A monopoly provider of a service has great power over its consumers as well as entrants that could threaten its dominance. An employer in a one-company town has the power to dictate not only how much its workers make. In a true company town, the employer also determines how workers are paid (for example, scrip rather than dollars) and how they spend their earnings (for instance, company-owned stores are the only retailers that accept scrip). It does not require exaggeration to say that capital has a great deal of power in both its purchasing and selling decisions and that workers and consumers have comparatively little power. To gloss over the power disparity between monopolistic and oligopolistic corporations and individual workers and consumers is to elevate the barren formalism of microeconomics over social realities.

The power of concentrated capital extends beyond the confines of the market sphere. The microeconomic concept of market power captures only one aspect of the power exercised by concentrated capital. Large corporations have the power to shape the long-term development of their industry by determining who gets to participate in their market and on what terms. They can also manipulate democratic politics, the media, and the ideology of a society. For example, they can fund trade associations, think tanks, and academics to influence the terms of popular debate and foster ideologies supportive of their interests (Kocieniewski 2013, Lipton \& Williams 2016). Corporate power, understood in its entirety, implicates political economy and cannot be cabined to control over the price of one commodity at one point in time.

Occupational and professional licensing regimes are established against the backdrop of extensive market-enabling state action and power disparities. They are not imposed on an anarchic or egalitarian marketplace. Rather, they are a layer of state action that structure markets, much like property and tort law. As with these common law fields, occupational and professional regulations shift legal entitlements and shape marketplace outcomes. They have the capacity to redress disparities in power. They can confer and amplify organizational force to atomized groups of workers. In doing so, they can create more equal — or at least less unequal—power relations between labor and capital.

\section{Antitrust Law's Intellectual Foundation and Analytical Framework Fail to Protect Consumers}

While the efficiency model can be reconciled to an extent with the consumer protection aspect of occupational licensing, it does not give consideration to the full range of consumer interests. Its horizon does not extend beyond the short term. The neoclassical paradigm, most 
familiarly expressed in supply-and-demand diagrams, is a static view of a market. Per this understanding, short-term market failures are valid grounds for state "intervention." Yet, markets do not exist at a single point in time. The present efficiency model fails to account for dynamic changes that can have far greater impact on consumers - for better or for worse - than static changes. In practice, the efficiency model can capture the static cost of a regulation but not its dynamic benefit. Antitrust law does have an analytical framework, the rule of reason, for balancing the benefits and costs of a particular public policy. Yet, because of its fixation on quantification, it is incapable of balancing the full range of benefits and costs.

The efficiency paradigm does recognize the possibility of market failures that warrant state action and thereby does acknowledge a limited role for occupation and professional regulations. In the textbook model, asymmetric information is a defining characteristic of some markets, especially those for complex services. Consumers lack the sufficient information to make fully informed decisions. For example, due to information asymmetries, consumers may not be able to tell a reputable medical practitioner from a quack seeking to make easy money (Akerlof 1970). Beyond paying for worthless service, consumers may suffer grievous harm because they cannot distinguish capable from incapable practitioners. An unqualified cardiologist can inflict great harm on patients, including incapacitation and death. The efficiency frame of contemporary antitrust deems such asymmetric information between consumers and service providers to be a market failure that warrant public action.

Licensing can correct for this asymmetric information between consumers and providers. It can establish impose educational and other training requirements for individuals seeking to offer a particular service. Occupational regulations screen market participants and ensure that only qualified professionals can legally serve the public. It establishes an entry barrier against incompetent and unqualified practitioners. Under such a licensing system, consumers are relieved of the burden of trying to distinguish competent practitioners from those who are not. Much like product standards, licensing rules can serve as a "market-stabilizing device ... in industries characterized by complex or highly technical products, where product quality is otherwise difficult to ascertain." (FTC 1983).

While it supposedly protects consumer interests, the current antitrust framework protects consumers in a very limited way. The efficiency model does not account for dynamic benefits from regulations, occupational or otherwise. For example, occupational regulations can raise wages and draw more skilled and diligent individuals into a field over a longer time horizon (Shapiro 1986). This can translate to superior quality and enhanced public safety. In other words, occupational licensing can reduce price competition today in exchange for higher levels of quality and safety in the future. Because of its static orientation, however, the efficiency frame does not capture these dynamic benefits. Instead, the efficiency lens sees only the short-term loss of price competition. 
Antitrust law's rule of reason, superficially sophisticated, is not capable of evaluating the benefits and costs of occupational regulation. In theory, it should be able to identify and balance competing objectives and considerations. Yet, in practice, it cannot achieve this goal. As with other prevailing forms of cost-benefit analysis, the rule of reason is comparatively good at measuring short-term and quantifiable costs and benefits and deficient in or even incapable of measuring longer-term and more qualitative benefits and costs (Allensworth 2016). In antitrust cases against mergers or monopolies, the rule of reason means that the plaintiff loses unless it can show actual or likely short-term price effects from the defendant's conduct (Stucke 2009). Dynamic and other more qualitative harms from, for example, a merger or monopoly are either discounted or disregarded.

The defects of the rule of reason become apparent in the context of public interest regulation. The costs of public interest regulation, including those governing occupational and professional licensing, tend to be quantifiable and incurred in the short run, whereas the benefits are more qualitative and more likely to accrue over a longer time horizon. ${ }^{2}$ Applying a rule of reason framework often means emphasizing the costs and discounting or ignoring the benefits. In the context of occupational regulations, a restriction on entry into a particular profession can raise prices in the short term but also improve the quality of service in the longer term. Given its bias in favor of quantifiable items, the rule of reason is likely to identify and condemn the shortterm loss of price competition and overlook any offsetting improvements to service quality over the long term. In practice, the rule of reason is biased against policies that have static, short-run costs and dynamic, long-run benefits. When forced to choose between a benefit that is not quantifiable and a cost which is, the rule of reason champions the quantifiable and ignores the non-quantifiable.

\section{The Existing Antitrust Paradigm's Narrow Lens Leads to Misguided Attacks on Occupational Licensing and Worker Collective Action}

The shift in antitrust philosophy from political economy to narrow microeconomics has brought occupational and professional regulations, as well as collective action by workers, into the enforcers' cross-hairs. The efficiency paradigm has led to collusion becoming the primary focus of antitrust enforcement, especially public enforcement. Without drawing distinctions between labor and capital, the antitrust agencies have made policing collective action by workers a focus of their enforcement and competition advocacy efforts. In doing so, they have insisted on viewing occupational and professional licensing within the narrow lens of their efficiency framework, rather than a consideration of larger public policies.

Under the efficiency framework, collusion has become the "supreme evil of antitrust." (Verizon Communications v. Law Offices of Curtis V. Trinko 2004). Conduct such as horizontal

\footnotetext{
${ }^{2}$ For example, cost-benefit analysis in the environmental context generally discounts longer-term benefits (Driesen 2006; Kysar 2010).
} 
price fixing between rivals is seen as almost always generating deadweight losses and no offsetting efficiency benefits. Today, collusion is subject to aggressive prosecution, with the Department of Justice's Antitrust Division focusing much of its resources on the criminal prosecution of individual and companies involved in price fixing and bid rigging (First \& Waller 2013). As collusion has moved to the center of the enforcement agenda, other forms of anticompetitive behavior have receded in importance. In elevating collusion to the rank of most serious antitrust offense, the antitrust agencies have neglected historical concerns about the concentration of private power. Over the past several decades, they have made merger and monopoly cases a lower priority. For example, the Department of Justice filed just one monopolization suit between 2006 and 2015 (U.S. Dep. of Justice, Workload Statistics).

With their collusion-centric enforcement philosophy and focus on eliminating restraints on horizontal price competition, the enforcement agencies, in particular the Federal Trade Commission, have made occupational and professional regulations a major priority (U.S. FTC 2016, United States 2016). Regulation of the occupations and professions often involves restrictions on entry and the establishment of price floors and supervision requirements. Because these regulations are often instigated at the behest of practitioners and impede full price competition, the antitrust agencies have been active participants in the campaign against them. They have called for a retrenchment of occupational regulations and argued that they should be limited to measures that protect consumers.

In addition to public advocacy against occupational regulations, the agencies have targeted private trade restraints among workers in their enforcement. They have brought enforcement actions against professional associations that adopted ethical codes and other rules that limited price competition among their members. In recent years, for instance, the FTC brought enforcement actions against professional associations representing music teachers and ice skating teachers for prohibiting their members from soliciting each other's clients (In re Music Teachers Ass'n 2014, In re Professional Skaters Ass'n 2015). Such suits against professional associations are not new for the FTC. For the antitrust agencies, collusion is collusion and should be subject to similar punishments, whether practiced by middle class workers seeking to establish some features of a market shelter or by the world's largest tech companies striving to suppress wages. Music and ice skating teachers who profit at the expense of parents of overachieving children may not be the most sympathetic defendants. The FTC, however, does not appear to restrict its activities to relatively privileged workers directly serving consumers. In fact, even collective action by workers to challenge powerful employers over low wages and unsafe working conditions is likely to draw the attention of the FTC (FTC v. Superior Court Trial Lawyers Ass'n 1990, Paul 2015).

These advocacy and enforcement efforts are misguided because they insist on viewing professional and occupational licensing through the framework of allocative efficiency. This technocratic concept is the proper goal of neither the antitrust laws in particular nor public policy 
in general. Occupational and professional regulations advance myriad goals. They can protect consumers in the short and long run and promote stable employment with livable wages. Antitrust enforcers, in joining the chorus against occupational and professional regulations disregard these other public policy aims and demand that legislators and regulators conform to their efficiency ideology.

\section{How Antitrust Agencies and Courts Should Respect the Objectives of Occupational and Professional Regulations in the Near Term}

Notwithstanding the narrow and inadequate efficiency paradigm of contemporary antitrust law, the federal antitrust agencies and the courts can still respect the objectives for occupational and professional regulations and ensure sufficient policy space for them. They can take two steps to ensure that occupational regulations are less likely to be subject to antitrust interference. First, the DOJ and FTC, in exercising prosecutorial discretion, should recognize that labor is not just another "commodity." Second, the agencies and the courts should maintain a state action immunity that gives states and municipalities freedom to enact and preserve occupational licensing without fear of antitrust liability.

\section{A. The Spirit of the Clayton Act's Labor Exemption Should, At a Minimum, Inform the Exercise of Prosecutorial Discretion}

The federal antitrust agencies should accord much lower priority to policing occupational regulation than they currently do. The current efficiency framework is not up to the task of evaluating occupational licensing regimes, even from a strict consumerist perspective. The efficiency ideology can offer only a partial understanding of the purposes and effects of occupational regulations. At best, it can provide some protection for consumers. At worst, this paradigm simplistically condemns occupational regulations as "publicly-approved cartels" and ignores their social benefits.

This exercise of prosecutorial discretion makes sense from a resource perspective. The agencies recognize that they cannot bring every case or opine on every matter that implicates competition policy. These capacity limitations are most acute during times of fiscal austerity, such as the present (Lipman 2013). In light of these constraints, the DOJ and FTC should place a much lower priority on policing occupational regulations and collective action by workers. These freed up resources can be devoted to areas that have been neglected in recent years and decades such as merger and monopolization matters. Even from a purely consumerist perspective, challenging an anticompetitive merger in food retailing or health insurance is sure to produce greater consumer savings than bringing a case against ice skating coaches for not soliciting each other's students.

A reduced focus on occupational regulation would promote the congressional spirit behind the Sherman and Clayton Acts. When the Sherman Act was being debated in 1890, a 
recurring concern was that courts would apply it to labor unions and other worker collectives on the basis that this joint action represented a "restraint of trade." The principal sponsors of the bill allayed this concern and stated it was aimed at capital, not labor (Paul 2016). Notwithstanding this understanding in Congress, the courts applied the Sherman Act to labor activities in the subsequent years (Loewe v. Lawlor 1908). Congress responded with the Clayton Act in 1914 and the Norris-La Guardia Act in 1935 to create space for collective labor activities (15 U.S.C. $§ 12$ ). The Clayton Act's labor exemption used expansive language, stating that "the labor of a human being is not a commodity or article of commerce."

A reduced focus on occupational regulation would further the original vision of the Sherman and Clayton Acts. Occupational regulations are, in part, intended to protect the interests of workers and promote higher wages and stable employment. Over the past century, the courts have construed the labor exemption narrowly and, in large measure, limited to the context of labor unions and collective bargaining rather than worker collective action more generally (29 U.S.C. $§ 101)$. Yet, this narrow understanding is a holdover from a different era with different labor market institutions, a period when stable centralized workplaces were the norm. This type of workplace is in long-term decline, replaced by a "fissured workplace" with independent contractor status becoming a new norm (Weil 2014). A broad understanding of the labor exemption would acknowledge changes in the labor market and recognize that those who depend on their labor for a living are workers, notwithstanding legal formalities and labels.

\section{B. The State Action Immunity Should Not Be Made More Restrictive}

The courts should not make the test for the state action immunity more restrictive. This immunity provides states with the flexibility to advance important public policies without running afoul of the antitrust laws. In the context of occupational licensing, the state action doctrine gives states and municipalities the freedom to establish regulations to protect consumers, improve wages and employment, and advance other public objectives.

The state action immunity reconciles the federal antitrust laws with state and local political authority. The Supreme Court has held that state action is immune from the antitrust laws. For instance, a state cannot be held liable for passing a law that restricts competition in a market (Parker v. Brown 1943). Private actors are entitled to the state action immunity if they can show that they are (1) acting pursuant to clearly articulated and affirmatively expressed state policy, and (2) subject to active supervision by the state (Cal. Retail Liquor Dealers Ass'n v. Midcal Aluminum, Inc. 1980). This doctrine represents a sensible balance between upholding the federal antitrust laws, respecting state and local policymaking powers, and protecting against the capture of these governmental units by private interests.

The Supreme Court in North Carolina State Board of Dental Examiners v. FTC (2015) clarified the application of the state action doctrine to regulatory bodies composed of private actors. The Court held that if a state agency is "controlled by active market participants," such as 
the dentists in the case, it would have to be actively supervised by a state entity. The Court noted that an agency controlled by active market participants is similar to a private trade association, except that the former acts under the color of state authority. According to the Court, in the absence of the active supervision requirement, powerful private actors could use state power to advance their own interests, rather than a broader public interest or state policy.

For state bodies controlled by active market participants, an important outstanding issue that the Court did not resolve what qualifies as "active supervision." It stated that "day-to-day involvement in an agency's operations or micromanagement of its every decision" is not required. It offered some guidance and stated that a supervising state actor "must review the substance of the anticompetitive decision . . . and have the power to veto or modify a particular decision." Unrealized potential for review is not sufficient.

To preserve occupational regulations, the active supervision requirement should not be made more restrictive. The Court's current guidance for what active supervision should be preserved, rather than made more prescriptive. In a number of areas across the states, occupational licensing bodies are controlled by active market participants. This choice is logical because active market participants are likely to have the expertise to serve as competent regulators of their field. As the Supreme Court noted though, these arrangements raise the risk of private interests being elevated over public goals. The Supreme Court's formulation of the active supervision requirement serves as reasonable check against this threat, without imposing onerous burdens on states.

To insist on more robust state oversight would create risks for occupational licensing regimes, and may even undermine the stated purposes of the Court. States could be compelled to establish "day-to-day supervision" of agencies controlled by active market participants or to replace active market participants with full-time officials. Retaining full-time government employees to oversee or staff these agencies may open entities like medical boards to even more political interference. And it seems both unnecessary and unaffordable at a time of tight budgetary constraints at the state level. If the state action doctrine is interpreted to demand such changes in the context of agencies controlled by active market participants, states may be forced to curtail or eliminate occupational licensure programs that advance important state policies. 


\section{Conclusion}

Technocrats have recently stepped up their attacks on occupational licensing regimes. They have criticized these regulations for raising consumer prices without providing sufficient offsetting health, safety, and other consumer benefits and for limiting entry into labor markets. These criticisms reflect an unduly narrow view of both consumer interests and the public interest. Evidence suggests that from a consumer protection angle many occupational licensing rules are too permissive and underenforced. Consumers appear to suffer serious harm, including grievous injury and death, because existing occupational licensing regimes are too weak. Moreover, occupational licensing is not intended to benefit consumers alone. By restricting entry, occupational and professional regulations establish market shelters that enhance the bargaining power of workers, raising wages and improving the welfare of workers. They function much as federal labor and minimum wage laws do and help establish floors on labor market standards.

Although many critics of occupational licensing have applied its framework, antitrust law, as presently interpreted, is not capable of fairly or fully evaluating occupational regulations. Under the efficiency objective of contemporary antitrust, goals aside from short-term wealth maximization are trivialized. For example, distributional fairness, protection of workers, and preservation of a democratic political economy are seen as "illegitimate." Notwithstanding the claims of its proponents, efficiency is neither apolitical nor value-free but rather conservative in orientation. Furthermore, the efficiency model assumes away power, disregarding the role of market-enabling state action and the supremacy of capital in modern society. Even from a consumerist view, the efficiency paradigm protects only a subset of consumer interests, principally short-term prices, and fails to fully consider other measures such as quality and safety. Rather than promote a broad understanding of the public good, efficiency-oriented antitrust authorities have launched misguided attacks on occupational licensing and worker collective action.

Federal antitrust authorities can still change course and not continue to demand that occupational regulations conform to their narrow efficiency objective. They can take two concrete steps to ensure political and policy space for occupational regulations. First, the DOJ and FTC should apply a broad interpretation of the statutory antitrust exemption for labor in exercising their prosecutorial and advocacy discretion. Second, they should preserve the existing interpretation of the state action immunity that preserves policy discretion for state and substate actors, including over the regulation of occupations.

Antitrust authorities should take a sober second look at the big picture of capital-labor relations over the past 50 years. While the prerogatives and wealth of concentrated capital have grown by leaps and bounds over the past half century, the main institutions of coordinated labor-unions - have precipitously declined, particularly in the private sector. Productivity gains 
have disproportionately benefitted the top $1 \%$, while wages stagnate. In that environment, one might expect it a foregone conclusion that antitrust enforcement would focus on its classic role of controlling the power of massive firms - rather than contriving new doctrine to unravel labor's belated and meager efforts at self-protection. Instead, antitrust authorities in both the Clinton and Obama administrations continued the Bush (père et fils) trend to shirk their responsibility to monitor and contain the monopolizing impulses of massive firms - especially in the technology and finance sectors (Khan \& Vaheesan, 2017). This trend is particularly troubling given the mounting evidence that information markets are being systematically distorted by large firms (Patterson, 2016; Ezrachi \& Stucke, 2016; Stucke \& Grunes, 2016).

Top economic officials in both the Obama and Trump administrations say that they want to assure workers good jobs at good wages. But the assertion rings hollow when they set out to undermine one of the key institutions offering some kind of stability in labor markets racked by precarity and disruption. The attack on occupational licensing is only a few steps removed from moves to undermine unions. If the Trump administration makes an assault on unionization a priority for its National Labor Relations Board, that might be a reversal of Democrats' NLRB policy - but will also have to be seen as a continuation of technocratic Democrats' antiprotectionist approach to labor. Unions, professional associations, and licensure requirements are mutually supportive and reinforcing policies designed to give workers some autonomy and selfdetermination in defining the terms of their employment. Undermining one tends to undermine the others.

Occupational licensing is just as much a matter of politics as it is of economics. Especially given persistent bias and opacity in the "economic science" of merger analysis, antitrust loses little if any scientific validity once it concedes the dually politico-economic nature of competition policy (Eisinger and Elliott, 2016). In properly politico-economic questions, both the ends and the means are open to debate, not dictated by a technocratic quest for a perfected labor market (McCluskey, Pasquale, and Taub, 2016).

Admittedly, existing occupational regulations can and should be improved. For example, they sometimes impede the full participation of former prisoners and immigrants in American economic life. The critical point is that occupational licensing implicates multiple, and sometimes competing, public policy goals, including protecting consumers and enhancing the bargaining power of workers. Licensure - part consumer protection, part labor law—calls for legislative-type determinations that reflect a broad and multifaceted conception of the public interest, not limited by esoteric formulations of efficiency that have by now lost whatever patina of legitimacy they once had. Antitrust practitioners who insist on reducing every public policy decision to efficiency-enhancing or efficiency-reducing cannot account for the pluralistic objectives of occupational licensing in particular and public policy in general. Given its intellectual narrowness, the framework of contemporary antitrust law provides a warped view of occupational and professional licensing regimes. 


\section{Literature Cited}

Akerlof GA. 1970. The market for 'lemons': quality, uncertainty and the market mechanism. Quarterly Journal Econ. 84:488-500.

Allensworth RH. 2016. The commensurability myth in antitrust. Vanderbilt Law Rev. 69:1-70.

California Retail Liquor Dealers Ass'n v. Midcal Aluminum, 445 U.S. 97 (1980).

Carstensen PC. 1983. Antitrust law and the paradigm of industrial organization. U.C. Davis Law Rev. 16:487-526.

Citizens United v. Federal Election Commission, 558 U.S. 310 (2010).

Davies W. 2014. Limits of Neoliberalism: Authority, Sovereignty, and the Logic of Competition. Thousand Oaks, CA: Sage.

Driesen DM. 2006. Is cost-benefit analysis neutral? Univ. Colorado Law Rev. 77:335-404.

Easterbrook F. 1984. Limits of antitrust. Texas Law Rev. 63:1-40.

Eastern Railroad Presidents Conference v. Noerr Motor Freight, Inc., 365 U.S. 127 (1961).

Economist. Too much of a good thing. 2016. The Economist, Mar. 26.

http://www.economist.com/news/briefing/21695385-profits-are-too-high-america-needsgiant-dose-competition-too-much-good-thing

Edlin E, Haw R. 2014. Cartels by another name: should licensed occupations face antitrust scrutiny? Univ. Pennsylvania Law Rev. 162:1093-1164.

Eisinger J and Elliott J. 2016. These Professors Make More Than a Thousand Bucks an Hour Peddling Mega-Mergers. ProPublica, Nov. 16, 2016.

Ezrachi A, Stucke ME. Virtual Competition. Cambridge, MA: Harvard Univ. Press.

Falls DS, Brittain A. 2014. In Virginia, Thousands of Day-Care Providers Receive No Oversight. Washington Post, Aug. 30.

Farivar C. 2016. DOJ, FCC, chairman ok Charter/Time Warner cable deal, with a few caveats. Ars Technica, Apr. 25. http://arstechnica.com/tech-policy/2016/04/doj-fcc-chairman-okchartertime-warner-cable-deal-with-a-few-caveats/

Federal Trade Commission v. Superior Court Trial Lawyers Ass 'n, 493 U.S. 411 (1990).

First A, Waller SW. 2013. Antitrust's democracy deficit. Fordham Law Rev. 81:2543-74.

Flynn JJ. 1988. The Reagan administration's antitrust policy, original intent and the legislative history of the Sherman Act. Antitrust Bulletin. 33:259-308.

Freidson, E. 1986. Professional Powers: A Study of the Institutionalization of Formal Knowledge. Chicago: University of Chicago Press.

Furrow B, Greaney T, Johnson S, Jost T, Schwartz R. 2013. Health Law: Cases, Materials and Problems. St. Paul, MN: West Academic. 7th ed.

Gellhorn W. 1976. The abuse of occupational licensing. Univ. Chicago Law Rev. 44:6-27.

Goldfarb v. Virginia State Bar, 421 U.S. 773 (1975)

Haberfeld M. 2016. Not everybody is an expert on policing. Zócalo, July 15. http://www.zocalopublicsquare.org/2016/07/15/not-everybody-expertpolicing/ideas/nexus/ 
Hale R. 1952. Freedom Through Law: Public Control of Private Governing Power. New York: Columbia University Press.

Hendrickson M, Heffernan W. 2007. Concentration of agricultural markets. Apr. http://www.foodcircles.missouri.edu/07contable.pdf

Hovenkamp H. 1985. Antitrust policy after Chicago. Michigan Law Rev. 84:213-84.

In re Music Teachers National Association. 2014. Federal Trade Commission no. 131-0118. https://www.ftc.gov/enforcement/cases-proceedings/131-0118/music-teachers-nationalassociation-inc-matter

In re Professional Skaters Association, Inc. 2015. Federal Trade Commission. No. 131-0168. https://www.ftc.gov/enforcement/cases-proceedings/131-0168/professional-skatersassociation-inc-matter

Kaplow L, Shavell S. 1994. Why the legal system is less efficient than the income tax in redistributing income. J. Legal Stud. 23:667-82.

Kaplow L, Shavell S. 2000. Should legal rules favor the poor? Clarifying the role of legal rules and the income tax in redistributing income. J. Legal Stud. 29:821-36.

Khan L, Vaheesan S. 2017. Market power and inequality: The antitrust counterrevolution and its discontents. Harvard Law \& Policy Rev. 11: forthcoming.

Kocieniewski D. 2013. Academics who defend Wall Street reap reward. New York Times, Dec. 28.

Kuttner R. 2008. Good jobs for Americans who help Americans. The American Prospect, Apr. 18. http://prospect.org/article/good-jobs-americans-who-help-americans

Lipman M. 2013. DOJ's antitrust plans unclear amid looming office closures. Law 360, Jan. 15. http://www.law360.com/articles/406994/doj-s-antitrust-plans-unclear-amid-loomingoffice-closures

Lipton E, Williams B. 2016. Scholarship or business? Think tanks blur the line. New York Times, Aug. 8.

Loewe v. Lawlor, 208 U.S. 274 (1908).

Manjoo F. 2016. Tech's 'frightful 5' will dominate digital life for foreseeable future. New York Times, Jan. 20. http://www.nytimes.com/2016/01/21/technology/techs-frightful-5-willdominate-digital-life-for-foreseeable-future.html

McCluskey MT. 2012. How the "unintended consequences" story promotes unjust intent and impact. Berkeley Law Raza Law J. 22:21-50.

McCluskey MT, Pasquale F., and Taub J., Law and Economics: Contemporary Approaches, Yale Law \& Policy Rev. (2016).

North Carolina State Board of Dental Examiners v. Federal Trade Commission, 135 S. Ct. 1101 (2015).

Orbach b. 2013. How antitrust lost its goal. Fordham Law Rev. 81:2253-278.

Parker v. Brown, 317 U.S. 341 (1943).

Pasquale F. 2006. Toward an ecology of intellectual property: lessons from environmental economics for valuing copyright's commons. Yale J. Law \& Tech. 8:78-135. 
Pasquale F. 2010a. Access to medicine in an era of fractal inequality. Annals Health Law. 19:269-310.

Pasquale F. 2010b. Dominant search engines: an essential cultural and political facility. In The Next Digital Decade: Essays on the Future of the Internet, ed. B. Szoka, A Marcus. pp. 401-18. Washington, DC: TechFreedom.

Pasquale F. 2010c. Reputation regulation: disclosure and the challenge of clandestinely commensurating computing. In The Offensive Internet: Privacy, Speech, and Reputation, ed. S Levmore and MC Nussbaum. pp. 107-23. Cambridge, MA: Harvard University Press.

Pasquale F. 2013a. Grand bargains for big data: the emerging law of health information. Maryland Law Rev. 72:682-772.

Pasquale F. 2013b. Paradoxes of digital antitrust. Harv. J. Law \& Tech. Occasional Paper Series. http://digitalcommons.law.umaryland.edu/fac_pubs/1433/

Pasquale F. 2013c. Privacy, antitrust, and power. George Mason Law Rev. 20:1009-24.

Pasquale F. 2014. Capital's offense: law's entrenchment of inequality. boundary 2 rev., Oct. 1. https://www.boundary2.org/2014/10/capitals-offense-laws-entrenchment-of-inequality/

Patterson M. 2016. Antitrust Law in the New Economy: Google, Yelp, LIBOR, and the Control of Information. Cambridge, MA: Harvard Univ. Press.

Paul SM. 2016. The enduring ambiguities of antitrust liability for worker collective action. Loyola Univ. Chicago Law J. 37:969-1048.

Pethokoukis J. 2014. The terrible economic burden of occupational licensing. Am. Enterprise Inst., Apr. 21. https://www.aei.org/publication/the-terrible-economic-burden-ofoccupational-licensing/

Piketty T. 2014. Capital in the Twenty-First Century, trans. A Goldhammer. Cambridge, MA: Harvard University Press.

Porter E. 2016. With competition in tatters, the rip of inequality widens. New York Times, July 12. http://www.nytimes.com/2016/07/13/business/economy/antitrust-competitioninequality.html

Powell L. 1971. Memorandum to Eugene Sydnor. Attack on American free enterprise system, Aug. 23.

http://law2.wlu.edu/deptimages/Powell\%20Archives/PowellMemorandumPrinted.pdf

Shapiro C. 1986. Investment, moral hazard, and occupational licensing. Rev. Econ. Stud. 53:84362.

Slivinski S. 2015. Bootstraps Tangled in Red Tape. Phoenix, AZ: Goldwater Inst.

Society of Professional Engineers v. United States, 435 U.S. 679 (1978).

Stucke ME and Grunes A. 2016. Big Data and Competition Policy. Oxford: Oxford University Press.

Stucke ME. 2009. Does the rule of reason violate the rule of law? U.C. Davis Law Rev. 42:13751490.

United Mine Workers v. Pennington, 381 U.S. 657 (1965). 
United States. Submission to Organisation for Economic Co-operation and Development. 2016. Disruptive Innovations in Legal Services, May 30.

https://www.ftc.gov/system/files/attachments/us-submissions-oecd-other-internationalcompetition-fora/1606disruptive_innovation-us.pdf

15 U.S. Code $\S 12$.

29 U.S. Code $\S 101$.

U.S. Department of Justice, Antitrust Division. Workload statistics, FY 2006-2015. https://www.justice.gov/atr/file/788426/download

U.S. Federal Trade Commission. 1983. Standards and Certification: Final Staff Report.

U.S. Federal Trade Commission. 2016. News release. FTC staff supports Department of Veterans Affairs proposed rule to grant full practice authority to advanced practice registered nurses. July 25. https://www.ftc.gov/news-events/press-releases/2016/07/ftcstaff-supports-department-veterans-affairs-proposed-rule

Vaheesan S. 2015. What iron pipefittings can teach us about public and private power in the market. Indiana Law J. Supp. 91:15-23.

Verizon Commc'ns., Inc. v. Law Offices of Curtis V. Trinko, 540 U.S. 398 (2004).

Vong v. Aune, 328 P.3d 1057 (Ariz. App. 2014).

Weil D. 2014. The Fissured Workplace: Why Work Became So Bad for So Many and What Can Be Done to Improve It. Cambridge, MA: Harvard University Press.

Whitman JQ. 2007. Consumerism versus producerism: a study in comparative law. Yale Law J. 117:340-407.

Whitney L. 2015. Apple, Google, others settle antipoaching lawsuit for $\$ 415$ million. C/Net News, Sept. 3. https://www.cnet.com/news/apple-google-others-settle-anti-poachinglawsuit-for-415-million/

Young, SD. 2002. Occupational licensing. In The Concise Encyclopedia of Economics, ed. DR Henderson. http://www.econlib.org/library/Enc1/OccupationalLicensing.html 